\title{
US Allies Respond
}

Japanese, Australian, and South Korean Reactions to China's Military

Modernisation

\section{Bonnie Glaser and David Szerlip}

\section{(2) OpenEdition}

\section{Journals}

Electronic version

URL: http://journals.openedition.org/chinaperspectives/5712

DOI: 10.4000/chinaperspectives.5712

ISSN: 1996-4617

\section{Publisher}

Centre d'étude français sur la Chine contemporaine

Printed version

Date of publication: 30 December 2011

Number of pages: 17-29

ISSN: 2070-3449

\section{Electronic reference}

Bonnie Glaser and David Szerlip, « US Allies Respond », China Perspectives [Online], 2011/4 | 2011,

Online since 30 December 2014, connection on 28 October 2019. URL : http://

journals.openedition.org/chinaperspectives/5712 ; DOI : 10.4000/chinaperspectives.5712

(c) All rights reserved 


\title{
US Allies Respond
}

\author{
Japanese, Australian, and South Korean Reactions to China's Military Modernisation
}

\author{
BONNIE GLASER AND DAVID SZERLIP*
}

\begin{abstract}
Japan, Australia, and South Korea, the three closest Asia-Pacific allies of the United States, have all reacted differently to the modernisation of the Chinese People's Liberation Army, depending on the immediate security situation that each faces. In Japan, which has been most directly affected by PLA Navy operations and other military capabilities, the response has been the most direct: increased investment in maritime and surveillance capabilities while also enhancing cooperation with the US and other like-minded partners in the region. For Canberra, the Chinese threat is still distant, but even down under, the reach and actions of the PLA are raising concerns, leading to plans for augmentation of military forces and a welcoming of permanently deployed US troops. Finally, in South Korea, the DPRK remains the primary threat, though China's recent unflinching support for Pyongyang has led to discussions about whether or not that decades-old security calculus should be re-evaluated.**
\end{abstract}

KEYWORDS: China, Japan, Australia, Republic of Korea, United States, defence policy, military modernisation, alliance, foreign policy, East China Sea, People's Liberation Army

A $s$ with others in the region, America's three closest allies in the AsiaPacific, namely Japan, Australia, and South Korea, have all faced a similar question over the past decade: what threat does China's military modernisation pose? Tokyo, Canberra, and Seoul have had to face an added wrinkle, however, as all three are forced to simultaneously calculate the strength and even the likelihood of future security guarantees from the United States.

Despite the similarities of the three economically developed democracies with close trade ties to China and a military alliance with the US, each has responded to China's military modernisation differently. Given its proximity and a recent history of encounters with an aggressive People's Liberation Army (PLA), Japan's reaction has been the most direct, altering its defence posture and investing in capabilities to defend its maritime interests. Australia has taken a similar approach, though its focus on the "China threat" is more recent and the resulting military adjustments are still unfolding. South Korea, on the other hand, is almost completely preoccupied by the North Korean threat and has only recently begun to consider the challenges posed by the PLA.

At the same time, all three allies have opted to strengthen ties with the US military, seeing this as the best - and cheapest - way to defend their national interests. Both Japan and South Korea are in the midst of basing adjustments designed to ensure a long-term American presence, and Australia recently announced enhanced US access to its military facilities in hopes of shoring up US military presence in the region. All three nations have also reached out to other potential regional partners, including each other but also India, Singapore, and Indonesia.

In this paper, we discuss the various reactions in Japan, Australia, and South Korea to the modernisation of the PLA. We explore the diverse perspectives in these countries, including official responses, military reactions, academic writings, and public opinion. By examining the different strands of thinking, we demonstrate that there is no uniform response to the Chinese military in any of the three countries. Even within these countries, opinions and reactions are subject to change based on other factors, such as politics and economics. The only common thread that can be identified is a trend of increasing concern about China's military, although no group in any country believes there is a high likelihood that Beijing will use force.

The long-term effects of China's military modernisation on the Asia-Pacific are unclear, but the potential fault line between China and the US has already begun to emerge. Although the governments of Japan, Australia, and South Korea hope that US-Chinese strategic competition can be controlled, each nation finds itself clearly aligned with the United States - though, depending on the success or failure of their current strategic reactions to the growth of the PLA, in a crisis that alignment may become murkier.

\section{Japan}

China's military modernisation and the increasing incursions of the PLA Navy (PLAN) in waters close to Japan have prompted a shift in emphasis from the Ground Self Defence Force (GSDF) to the Maritime Self Defence Force (MSDF) and a strengthening of ties with the United States, Australia, and South Korea - all accomplished without increased defence spending. A growing number of Japanese fear that the PLA's acquisition of enhanced long-range operational capabilities will embolden China to look beyond Taiwan and its immediate environs, a scenario that could entail more frequent incursions into Japanese waters. More alarmist opinions contend that China may be seeking control of the ocean region between Okinawa's main island and Miyako Island and could divide Japanese territory to the west of Miyako. (1)

Bonnie Glaser is a senior fellow in the Freeman Chair in China Studies at the Center for Strategic and International Studies (CSIS) in Washington DC and a senior associate at Pacific Forum, CSIS. David Szerlip is a consultant for the US government on issues related to Chinese military modernisation and a former researcher for the Freeman Chair in China Studies at CSIS.

** The authors are deeply grateful to CSIS intern Jackson Nichols for his research and writing assistance.

1. "Chinese Nuclear Submarine Breaks Through First Island Chain of Defense in February 2009 between Islands of Miyako and Yonaguni," Sankei Shimbun, 4 January 2011. 


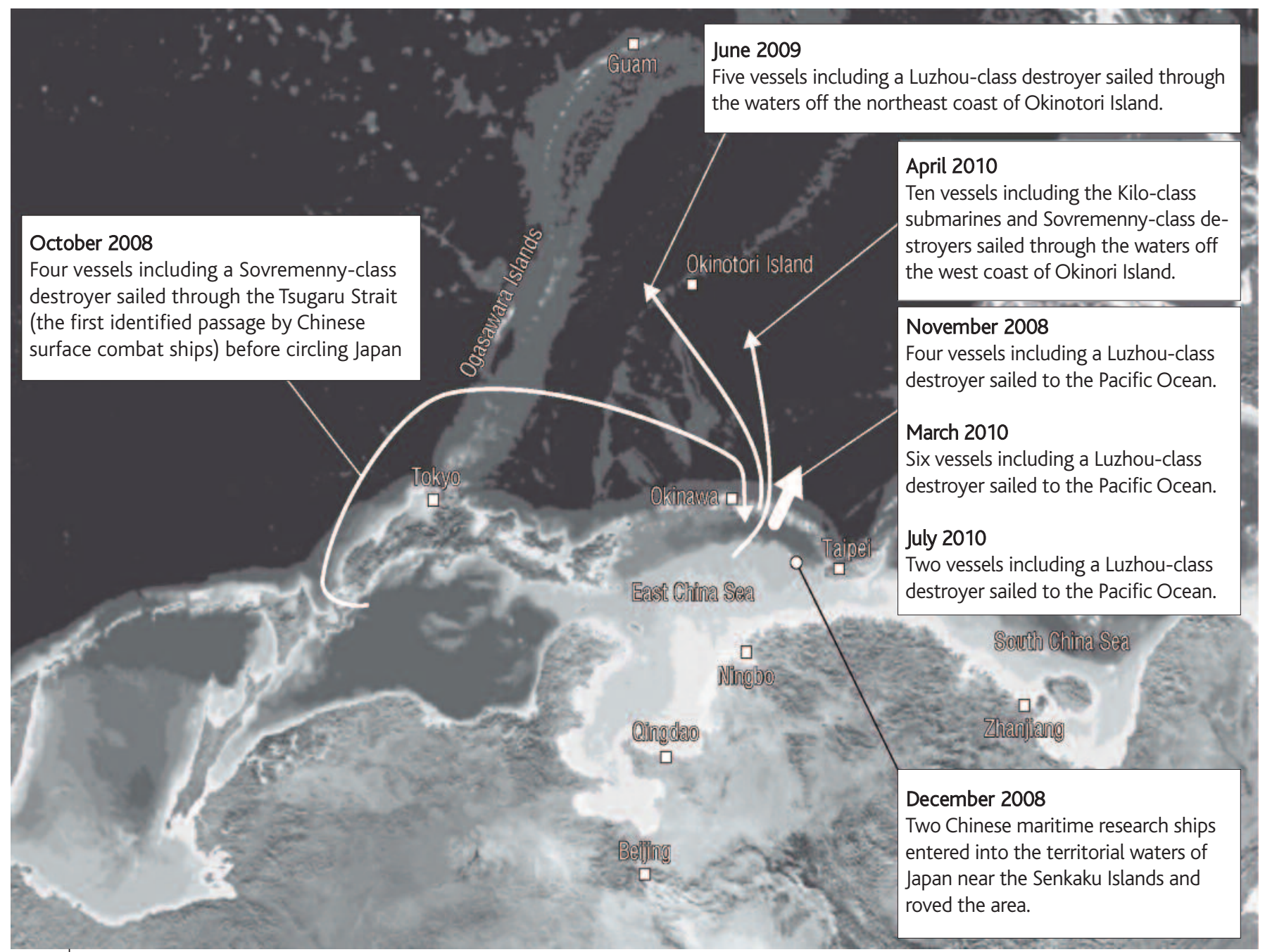

Recent PLA activities near Japan.

Source: Japanese Ministry of Defense, "Defense of Japan" (Annual White Paper) Chapter 2, Section 3: China, p. 62, 2010, www.mod.go.jp/e/publ/w_paper/2010.html (consulted on 30 November 2011).

Reacting to calls from academics, the public, and a government-commissioned study group, the Democratic Party of Japan (DPJ) unveiled a new proactive security strategy termed the Dynamic Defence Force that raises the profile of the MSDF and commits significant defensive and surveillance assets to Japan's southwestern islands in response to China's expanding maritime activities in waters surrounding Japan, including sailing patrol vessels into Japan's territorial waters. (2) However, the strategy's implementation will be challenged by a stagnant defence budget and the effects of the March 2011 earthquake, leaving persistent questions about whether Japan can marshal the necessary resources to counter China's increasingly assertive posture in the East China Sea.

\section{Official responses}

While official Japanese documents refrain from labelling China as a threat, the growing angst is unmistakable. The 2004 National Defence Program Guidelines (NDPC) laid down a marker, noting that Tokyo would be "attentive" to China's future intentions. ${ }^{(3)}$ In the 2010 Defence White Paper, the terminology progressed to "concern" over the lack of transparency in China's military programs, defence budget, and overall security policy. ${ }^{(4)}$ A 2010 government-commissioned group that studied Japan's future defence capabilities cited advances in China's naval, missile, and air forces, and the development of asymmetric capabilities in space and cyberspace, and noted that the cross-Strait military balance with Taiwan was shifting in China's favour. ${ }^{(5)}$ The 2011 Defence White Paper highlights how the level of transparency in China's military modernisation and decisionmaking continue to fall short of the levels expected of a responsible major power. ${ }^{(6)}$ Using unusually harsh language, it describes China as "expanding and intensifying" its maritime activities in waters strategically important to Japan. The document cites numerous instances of military exercises, monitoring activities, and "advancements to the Pacific Ocean" by Chinese naval surface vessels. For example, in April 2010 and June 2011, large flotil-

2. "China Boats Enter Waters Off Senkakus," Yomiuri Shimbun, 25 August, www.yomiuri.co.jp/dy/ national/T110824006192.htm (consulted on 13 December 2011).

3. Heng Yee Kuang, "Best Not to Push Japan into a Corner," The Straits Times, 21 December 2010

4. Japan's National Defense Program Guidelines, produced every two years, are distinct from the Defense White Paper, which is produced annually.

5. The Council on Security and Defense Capabilities in the New Era, "Japan's Visions for Future Security and Defense Capabilities in the New Era:Toward a Peace Creating Nation," 2010

6. Japanese Ministry of Defense, "Defense of Japan" (Annual White Paper) 2010, www.mod.go.jp/e/publ/w_paper/2010.html (consulted on 30 November 2011). 
las of PLAN submarines and warships passed between Okinawa's main island and Miyako Island, conducting live-fire exercises en route in what a Japanese Defence Ministry source called "a brazen show of force." (7)

According to the White Paper, Chinese maritime activities are aimed at intercepting naval operations by enemies in waters as far as possible from Chinese territory; deterring and preventing Taiwan independence; acquiring, maintaining, and protecting China's maritime rights and interests; and defending the sea lanes of communications. The White Paper forecasts that China "plans to expand its sphere of maritime activities" in the waters surrounding Japan and calls for greater attention to Chinese naval and surveillance operations. ${ }^{(8)}$

One fear in Tokyo is that China could begin to dispatch armed "fisheries patrol ships" to the East China Sea, as it has done in the South China Sea, in an effort to exercise sea control under the guise of protecting fishing boats. ${ }^{(9)}$ The PLAN has also increased its information-gathering activities, including oceanographic research within Japan's Exclusive economic zone (EEZ). In June 2011, a Chinese ocean research vessel was detected in Japan's EEZ investigating seawater contamination caused by the accident at the Fukushima no. 1 power plant. ${ }^{(10)}$ According to Japanese media, the penetration of PLAN submarines between the Miyako and Yonaguni islands indicates that the PLAN has acquired an understanding of ocean floor topography, and has improved the quieting of its submarines, which constitute significant operational and technical developments. ${ }^{(11)}$ In addition, Air Self-Defense Forces (ASDF) jets were scrambled to ward off Chinese planes 96 times in fiscal year (FY) 2010, double the number in FY2009. While no aircraft actually violated Japanese airspace, in March 2011 two Chinese Y8 surveillance planes crossed the median line between Japan and China and came close to Japanese airspace over the Senkaku Islands for the first time. ${ }^{(12)}$

When physical confrontations between Japanese and Chinese vessels have occurred, Chinese explanations of the incidents have failed to satisfy Japanese officials. For example, after PLAN helicopters buzzed MSDF vessels in April 2010, Foreign Minister Okada Katsuya rejected China's contention that the helicopters were performing necessary defensive acts and insisted that the MSDF was performing surveillance in accordance with international law. ${ }^{(13)}$ In the most serious incident from a diplomatic perspective, in September 2010, a Chinese fishing trawler deliberately rammed two Japan Coast Guard (JCG) vessels off the Senkakus. Tokyo's decision to detain the captain provoked a harsh response from Beijing, including diplomatic protests, cancellation of high-level official meetings and cultural exchanges, restrictions on rare earth mineral exports to Japan, and demands for compensation, all of which led to a deterioration in bilateral relations.

The 2011 China Security Report by Japan's National Institute for Defence Studies (NIDS) notes that the PLA's operations are sometimes incompatible with principles and practices shared by the international community, such as freedom of navigation. And while the PLA has embraced military diplomacy with other nations to reduce suspicion about its modernisation, military exchanges with Japan have been limited as China continues to condition such exchanges on progress in the overall political relationship between the two nations. The NIDS report advocates steps to prevent accidents and defuse crises should they occur. Although a Joint Working Group between the defence authorities of the two nations has met twice since 2008, a bilateral crisis communications mechanism has yet to be established. (14)

In December 2010, Japan released the NDPG for 2011, detailing a new security strategy that is largely a reaction to China's increasing naval ac- tivities in waters surrounding Japan. Deputy Defence Minister Jun Azumi stated "We must put priority on strengthening our defence capability in the south and the west, looking toward China." (15) Japan will no longer rely on the "Basic Defence Force Concept," which was introduced in 1976 and relied on a minimum capability to defend Japan against the threat posed by the Soviet Union; instead, Japan will develop a "Dynamic Defence Force" that possesses readiness, mobility, flexibility, sustainability, and versatility, reinforced by advanced technology and intelligence capabilities. ${ }^{(16)}$ The NDPG redirects the traditional focus away from the GSDF and the threat of a full-scale land invasion of the Japanese home islands to defence of Japan's maritime domain, particularly in the southwest, including the remote Nansei Islands. It calls for a redirection of manpower and defensive platforms, including placing assets on previously unoccupied islands.

The NDPG represents a major step for the DPJ, which was seen as weak on defence due to its failure to forcefully stand up to China in the wake of maritime incidents. Upon assuming office in 2009, Prime Minister $\mathrm{Ha}$ toyama emphasised establishing an equidistant posture between Washington and Beijing. His mishandling of foreign policy, in particular a domestic funding scandal and the issue of the relocation of the US Marine Corps Air Station Futenma in Okinawa, resulted in his replacement by Naoto Kan in 2010. The DPJ was also criticised for the delayed release of the 2010 White Paper and the NDPG, which some argued hindered Japan's ability to undertake defensive countermeasures against China. ${ }^{(17)}$

While the release of the NDPG has silenced some DPJ critics, the FY2011 draft defence budget revealed a 0.4 percent drop in funding to 4.66 trillion yen (USD 56.8 billion), the ninth consecutive year of reductions. ${ }^{(18)}$ Thus, Japan will have less funding with which to implement the new defence strategy. Cooperation with other countries, or what the NDPG terms "multilayered security," is therefore a cornerstone of the strategy. Following a rough stretch in 2009 and 2010, the Japan-US alliance appears solid. In the

7. Hajime Furukawa, Yuko Mukai, "New Japan-US Coals Focus on China's Rise," Yomiuri Shimbun, 23 June 2011; "Japan to investigate China warships near Okinawa," Reuters, 14 April 2010; Edward Wong, "China Navy Reaches Far, Unsettling the Region," The New York Times, 14 June 2011.

8. Japanese Ministry of Defense, "Defense of Japan" (Annual White Paper) 2011.

9. "China 'Must Respect International Law': Obama Answers Yomiuri Questions on Asia Security, Alliance," Yomiuri Shimbun, 13 November 2010.

10. Kenji Minemura, "Chinese Ship Inside Japan's EEZ to Survey Radiation," Asahi.com, 29 June 2011, www.asahi.com/english/TKY201106280235.html (consulted on 30 November 2011).

11. "Chinese Nuclear Submarine Breaks Through First Island Chain of Defense in February 2009 between Islands of Miyako and Yonaguni," art. cit.

12. "Airspace Border Tensions Soar: ASDF Scrambled 386 times to Ward Off Foreign Aircraft in FY10," Yomiuri Shimbun, 10 April 2011.

13. James J. Przystup, "Japan-China Relations," Comparative Connections, vol. 12, no. 2, July 2011.

14. Japanese National Institute for Defense Studies, "NIDS China Security Report," 2011, p. 35, www.nids.go.jp/english/publication/chinareport/pdf/china_report_EN_4C_A01.pdf (consulted on 30 November 2011).

15. Gordon Arthur, "Imperial Defence-Japan Counters China's Military Confidence," Jane's Intelligence Review, 7 March 2011, http://articles.janes.com/articles/Janes-Intelligence-Review-2011/Imperial-defence-Japan-counters-China-s-military-confidence.html (consulted on 30 November 2011).

16. Japanese Ministry of Defense, "National Defense Program Guidelines for 2011 and Beyond," 7 December 2010, p. 7, www.mod.go.jp/e/d_act/d_policy/pdf/guidelinesFY2011.pdf (consulted on 30 November 2011).

17. For example, see the editorial "Security and Defense Council Should Discuss Making Preparations Against Growing Threats," Sankei Shimbun, 24 February 2010. The editorial criticises the effect that the NDPG's postponement has on the defence budget. On the other hand, some argue that it was natural for the new government to undertake a lengthy review of security policy. This line of thinking is supported by the DPJ's establishment of the "Council on Security and Defence Capabilities for a New Age" a gathering of experts that was presided over by Prime Minister Hatoyama himself, and which examined the build-up in China's military capabilities. The Council's recommendations exerted a strong influence on the NDPG.

18. "Imperial Defence-Japan Counters China's Military Confidence," art. cit. 


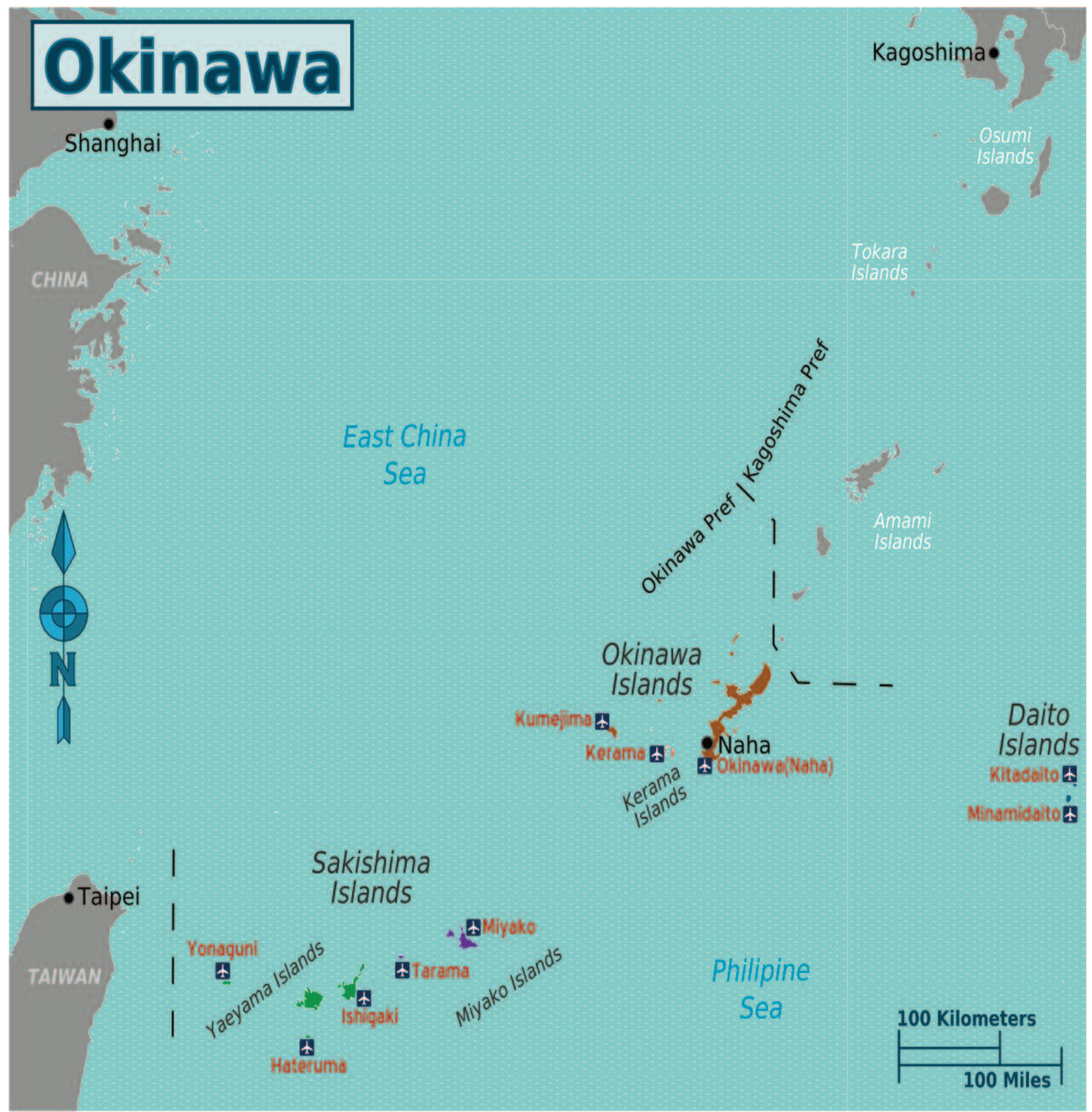

Map of Okinawa and Sakashimi Islands.

Wikitravel, http://wikitravel.org/shared/Image:Japan_Okinawa_map.png (consulted on 30 November 2011).

wake of the Senkaku incident and North Korea's provocative actions, the government of Japan has concluded that the US military presence positively contributes to its security environment and is eager to strengthen the alliance. At the 2010 APEC summit, Prime Minister Kan publicly recognised the importance of the US presence in Asia, and in December of that year, Japan and the US carried out major military exercises. In June 2011, Japanese and US foreign and defence ministers convened the Security Consultative Committee, where both sides agreed to postpone the contentious relocation of the US Marine CorpS
Air Station Futenma until after 2014 and reached agreement on new "common strategic objectives," including joint goals in their relations with China. The participants discussed "non-traditional security concerns" in outer space, the high seas, and cyberspace, and reaffirmed the importance of freedom of navigation throughout regional waters, all veiled allusions to concerns prompted by Chinese actions in recent years. The joint statement called for China's "adherence to international norms of behaviour" and urged the improved openness and transparency of its growing military. The statement also highlighted the im- 
portance of cooperation between Japan, the US, and other regional countries such as Australia and South Korea. ${ }^{(19)}$

The NDPG also prioritises cooperation with South Korea and Australia in bilateral as well as multilateral initiatives with the US, ASEAN, and India. (20) In 2007, Japan and Australia signed an unprecedented security declaration promoting cooperation on border security, counterterrorism, disaster relief, and strategic assessments. The following year, both sides agreed to expand military exercises and hold regular security consultations. In 2010, an Acquisition and Cross-Servicing Agreement (ACSA) was formalised, allowing the Japan Self-Defence Forces (JSDF) and the Australian military to mutually provide transportation, accommodation, maintenance, and health services, and marking Japan's first such agreement with a country besides the US. (21) The first-ever joint naval exercise by the US, Japan, and Australia was held in the South China Sea in July 2011. One month after North Korea attacked South Korea's Yeonpyeong Island (November 2010) and five months after China warned the US not to carry out carrier-based exercises with the Republic of Korea (ROK) in the West Sea (July 2010), South Korea joined the US-Japan exercises as an observer for the first time in December 2010, demonstrating solidarity among the three countries. Against the background of North Korea's military provocations and China's increased maritime activity, the US has encouraged further cooperation between Japan and South Korea. In a January 2011 meeting, Japanese and South Korean defence ministers pledged to enhance cooperation. (22)

\section{Military reactions}

In response to stepped-up Chinese naval activity in the East China Sea, the JSDF must expand its range of operations without a concurrent increase in resources; therefore Japan will dramatically rationalise and streamline the JSDF. The defence budget has cut back procurement of arms for the GSDF and made the MSDF the preeminent military branch under the revised approach to defending Japan. Outdated equipment and organisations will be reduced across services, the location and operational modality of forces will be reassessed, and budget allocation will be subject to "drastic review." (23) In order to implement the NDPG's findings, the Ministry of Defence (MOD) has established a committee to find ways to enhance operational capabilities through integration of the different services. The committee raised issues such as mobile deployment, command and control, and warning and surveillance capabilities. It also developed scenarios involving the JSDF engaging in operations to take back the Senkakus after an illegal landing by persons pretending to be fishermen or an invasion by the Chinese military. (24)

In response to growing concerns about threats from China, increasing defensive capability throughout the southwestern Nansei Island chain has become a national priority. Ground, air, and naval forces will be increased in the far southern islands. One hundred GSDF members will be deployed for the first time on Yonaguni, (25) Japan's westernmost island, and consideration is being given to building a monitoring station on Yonaguni to track the movements of Chinese vessels in the East China Sea using optical equipment and radar. (26) Mobile units will assist in the event of attacks, making the improvement of ASDF transport capabilities for deploying units crucial. Joint rapid-response exercises will be increased in preparation for such scenarios. Japan will deploy ground-based anti-ship missiles and dispatch another F-15 squadron to Okinawa, effectively doubling the number of fighter aircraft deployed in the south. (27)
Intelligence and surveillance assets will also be increased, including unmanned surveillance aircraft and coastal surveillance units with groundbased radar. ${ }^{(28)}$ In addition, MOD will purchase ten new Kawasaki P1 patrol planes to monitor submarines and suspicious boats operating near Japanese territorial waters. These planes will replace half of the P3C planes now used for missions such as taking photos of the disputed Shirakaba/Chunxiao gas field in the East China Sea. ${ }^{(29)}$ An agreement was reached with Beijing in June 2008 to establish a joint development zone and finalise a treaty, but bilateral friction has hampered implementation. In March 2011, China reportedly began drilling off the gas field, prompting Japan to express regret. (30) The MOD intends to prioritise issues that must be dealt with immediately and these needs will be reflected in budget requests for the FY2012 draft budget. (31)

For the first time in 30 years, Japan's fleet of diesel-electric submarines is expanding, from 16 to 22 . Although numerically inferior to China's fleet of roughly 60 submarines, Japanese submarines are world-class and will conduct surveillance and defensive missions. Japan's Aegis-equipped destroyer fleet with ballistic missile defence (BMD) capability is also increasing from four to six, and last year the MSDF and US Navy deployed a certified sea-based theatre BMD capability. Four new Akizuki-class destroyers will be procured to protect the Aegis destroyers. Japan is also planning to field new "helicopter destroyers" that are ideal for anti-submarine warfare. ${ }^{(32)}$

The Japan Coast Guard has recently emerged as a fourth military branch with considerable surveillance responsibility. Unlike other JSDF branches, the JCG has a positive image free from association with Japan's militaristic history. According to Richard J. Samuels, the modernisation and expansion of the JCG enhances Japan's power projection capabilities and allows it to project influence without the destabilising consequences of a major defence budget increase. As the JCG's patrolling authority has grown, pressure has built to enhance the JCG's combat capabilities by adding capabilities such as a modern weapons suite, armaments, and sensors. (33)

Although the MSDF holds a qualitative advantage over China in many areas, concerns persist that it lacks the quantitative resources needed in its

19. "New Japan-US Goals Focus on China's Rise," art. cit.

20. National Defense Program Guidelines for 2011 and Beyond, op. cit., p. 9, www.mod.go.jp/e/d_act/ d_policy/pdf/guidelinesFY2011.pdf (consulted on 30 November 2011).

21. "Japan, Australia Sign Defence Logistics Accord," BBC Monitoring Asia Pacific, 19 May 2010.

22. "Japan, S. Korea Must Boost Security Cooperation," Yomiuri Shimbun, 11 January 2011.

23. National Defense Program Guidelines for 2011 and Beyond, op. cit., p. 13, www.mod.go.jp/e/d_act/d_policy/pdf/guidelinesFY2011.pdf (consulted on 30 November 2011).

24. "MOD Revealed To Have Made Contingency Scenarios for Taking Back Senkaku Islands Seized by China," Sankei Shimbun, 9 May 2011.

25. "Ministry of Defense to Station 100 GSDF Members on Island in Okinawa to Observe China," Mainichi Japan, 10 November 2010.

26. "Yonaguni plot eyed for GSDF monitoring post," Kyodo, 21 August 2011

27. "Imperial Defence-Japan Counters China's Military Confidence," art. cit.

28. Mid-Term Defense Program (Fy2011-Fy2015), approved by the Security Council and the Cabinet on 17 December 2010, www.mod.go.jp/e/d_act/d_policy/pdf/mid_termFY2011-15.pdf (consulted on 30 November 2011).

29. House of Japan, 18 November 2010, http://www.houseofjapan.com/local/japan-will-buy-10-p1-patrol-planes (consulted on 30 November 2011).

30. "Edano Slams Reported China Drilling in Gas Field," Kyodo, 9 March 2011.

31. "MOD Revealed To Have Made Contingency Scenarios for Taking Back Senkaku Islands Seized by China," art. cit.

32. "Imperial Defence-Japan Counters China's Military Confidence," art. cit.

33. Richard J. Samuels, "New Fighting Power! Japan's Growing Maritime Capabilities and East Asian Security," International Security, vol. 32, no. 3, Winter 2007/2008, p. 100. 
enhanced role. The MSDF lacks auxiliary ships, as new ships essentially replace those retired due to normal attrition. Additionally, while unmanned aircraft have been prioritised, cost estimates for four Global Hawks for 24hour surveillance reach the tens of billions of yen (hundreds of millions of euros), leading one senior official to argue that "Under current fiscal conditions, we could not afford to purchase them." (34) The US will shoulder some of the burden. In December 2010, American and Japanese forces exercised defending remote islands in Keen Sword, which involved 34,000 JSDF personnel and 40 warships, along with 20 US vessels. ${ }^{(35)}$ Other joint initiatives will emphasise enhancing cyber and information security, reducing vulnerabilities to possible threats from China. The MSDF has also participated in international missions in the Gulf of Aden and hopes such endeavours will increase readiness and operational capability. In sum, the JSDF aims to spread its limited assets across a broad maritime domain in a manner that allows it the flexibility to quickly detect and respond to contingencies involving China.

\section{Academic reactions}

Japanese scholars have become increasingly concerned with China's military build-up. Sumihiko Kawamura of the conservative Okazaki Institute believes Japan cannot ignore China's aggressive behaviour. He argues, "The majority of Japanese perceive that China is increasing assertiveness and threatening Japan," and Japan must therefore strengthen its military. ${ }^{(36)}$ From this perspective the NDPG's new strategy is seen as a positive move. Professor Takashi Kawakami maintains that the shift in strategy was necessary. He emphasises the need to hedge and balance against China to prevent it from exploiting a military vacuum, just as the former Soviet Union did with the islands off Hokkaido. Regarding the new focus on the southwestern islands, Kawakami states, "There is a deterrent effect and I think it sends a big message to China." (37) Other Japanese scholars view China as posing a long-term threat and urge that greater attention be paid to the more immediate danger from North Korea. For example, Tokyo University's Yoshimitsu Nishikawa agrees that shifting defence policy to deal with the challenges posed by China is necessary, but worries that a North Korean contingency could negatively affect Japan's security in the near term. ${ }^{(38)}$

Japanese scholars are also discussing the Japan-US alliance and its role in deterring Chinese aggression. Yoshihide Soeya of Keio University maintains that the alliance serves the country's strategic needs and predicts that China's assertiveness will drive Japan closer to the US. He argues, "Without the alliance, Japan cannot deal with the modernization of China's military and its increased activities." (39) Yet other Japanese scholars worry about US staying power over the long run and the viability of the US deterrent. Yasuhiro Matsuda notes that China's development of area-denial capabilities and space-war technology could inhibit the US Navy's freedom of navigation and damage US satellite networks. ${ }^{(40)}$ One suggestion to bolster the alliance is the AirSea Battle Concept contained in the US Quadrennial Defence Review, which is likely intended as a hedge against China. It entails greater integration of JSDF and US intelligence and warning systems, and could require greater Japanese contributions to BMD development and the expansion of anti-submarine barriers throughout the southwest Pacific. Some Japanese are sceptical as to whether the concept will be operationalised, however, and argue that given Japan's budget woes, the NDPG may represent a sounder strategy. ${ }^{(41)}$

\section{Public opinion}

Japanese public opinion polls reveal growing public distrust of China. In a November 2009 poll, 69 percent of respondents found China either "not very trustworthy" or "not trustworthy." (42) In another 2009 survey, over 54 percent of respondents considered Japan-China relations to be "not so good" or "not good." (43) Feelings quickly hardened after the September 2010 Senkaku incident, with a record 84 percent of respondents finding China untrustworthy. Ninety-four percent said Chinese demands for an apology and compensation were unacceptable, ${ }^{(44)}$ and 79 percent felt a military threat from China. ${ }^{45)}$ Newspaper editorials excoriated China's decisions to curtail dialogue on joint energy exploration in the East China Sea and restrict exports of rare earths, and suggested that Chinese foreign policy was increasingly at the mercy of hardliners. The Senkaku incident was voted the news story of the year in a poll of junior high school students. ${ }^{(46)}$ In a more recent survey, a March 2011 BBC World Service poll revealed that 88 percent of Japanese had a negative reaction to China becoming more powerful militarily. ${ }^{(47)}$

The Japanese public's concern goes beyond China's conventional weapons development to include modernisation of its nuclear arsenal. For example, a January editorial expressed concern over the sincerity of China's "no first use" policy for nuclear weapons. ${ }^{48)}$ A public opinion survey revealed that 80 percent of respondents are apprehensive about the nuclear arms situation in Northeast Asia and want discussion on the nuclear issue within both the government and the Diet. ${ }^{(49)}$ This does not necessarily suggest that there is growing support for the acquisition of nuclear weapons by Japan; rather it indicates that a growing number of Japanese demand an informed debate about Japan's security environment and its strategic defence options.

Reflecting public angst, an Asahi Shimbun editorial lamented the Chinese public's failure to criticise rising defence spending. It concluded that

34. "High Costs Could Ground Aerial Reconnaissance Activities," Asahi Shimbun, 24 February 2011.

35. "S. Korea to Join in Japan-US Defense Drills as Observer," Japan Economic Newswire, 2 December 2010

36. Wendell Minnick, "Will Japan's Troubles be China's Boon?" Defense News, 21 March 2011.

37. Close Protection World Area, Worldwide Security News, 18 December 2010, http://www.closeprotectionworld.com/security-news-asia/41851-japan-defense-more-muscular-china-made-change-necessary.html (consulted on 30 November 2011).

38. "More Muscular China Made Change Necessary," The Japan Times, 18 December 2010.

39. "Best Not to Push Japan into a Corner," art. cit.

40. Yasuhiro Matsuda, "Taiwan in the China-Japan-US Triangle," in Gerald Curtis, Ryosei Kokubun, and Wang Jisi (ed.), Getting the Triangle Straight: Managing China-Japan-US Relations, Japan Center for International Exchange, 2010, pp. 123-143.

41. "China's New Missile Capabilities Raises Tension," Asahi Shimbun, 27 January 2011.

42. "November 2009 Japan-China Joint Public Opinion Poll," Yomiuri Shimbun, 29 September 2009, www.mansfieldfdn.org/backup/polls/2009/poll-09-29.htm (consulted on 13 December 2011).

43. "The Cabinet Office of Japan 2009 Public Opinion Survey on Diplomacy," Nikkei Shimbun, 29 December 2009, www.mansfieldfdn.org/backup/polls/2009/poll-09-35.htm (consulted on 13 December 2011).

44. "Public Opinion of China Slumps/After Senkaku Incident, Record-High 84\% Don't Trust Country," Yomiuri Shimbun, 5 October 2010.

45. "Distrust Clouding Japan-China ties," Yomiuri Shimbun, 8 November 2010.

46. "Best Not to Push Japan into a Corner," art. cit.

47. BBC Global Poll, "Rising Concern about China's Increasing Power: Clobal Poll," 27 March 2011, www.worldpublicopinion.org/pipa/pdf/mar11/BBCChina_Mar11_rpt.pdf (consulted on 30 November 2011).

48. "China's Nuclear Policy - Doubts Remain About China's 'No-First-Use of Nuclear Weapons," Sankei Shimbun, 13 January 2011

49. "Opinion Survey on Security - Issue of Bringing in of Nuclear Weapons Should be up for Discussion," Sankei Shimbun, 15 February 2011. 
favourable public sentiment toward the military would keep China's defence budget growing for the foreseeable future. ${ }^{(50)}$ Highlighting the close military ties of $\mathrm{Xi}$ Jinping, who is expected to become the next Chinese Communist Party General-Secretary, a Sankei Shimbun editorial suggested that Xi's rise to power could be accompanied by an increase in PLA influence on the Party. ${ }^{(51)}$ A Yomiuri Shimbun editorial noted the controversy over China's alleged labelling of the South China Sea as a "core interest" and predicted that Beijing would expand the term to include the East China Sea. ${ }^{(52)}$ Given such sentiment, the Japanese public will likely maintain pressure on the government to remain firm towards China.

\section{Post-earthquake effects}

The March 2011 earthquake and tsunami prompted an immediate pledge of support for Japan from Chinese President $\mathrm{Hu}$ Jintao, but the positive impact on bilateral relations was limited, as news surfaced shortly thereafter that China's patrols in the East China Sea continued unabated. For example, on 7 and 26 March, a Chinese helicopter buzzed a MSDF ship in international waters in the East China Sea. ${ }^{(53)}$ With debt approaching 200 percent of GDP and post-earthquake reconstruction costing hundreds of billions of US dollars, Tokyo will likely have to rethink its national security priorities. Officials have tried to downplay the effect on defence, yet there are concerns that the crisis will affect JSDF funding as government revenue and spending is reduced. The JSDF may face pressure to fund enhanced disaster response capability at the expense of improving combat capability, and funds could even be reallocated from the integrated air and missile defence program to operational budgets. Japan may also reduce its involvement in international peacekeeping efforts. Tokyo's plan to purchase $50 \mathrm{FX}$ fighters to upgrade its aging fleet appears to remain on track, however, suggesting that Japanese officials remain committed to longterm strategic priorities set prior to the March disaster. ${ }^{(54)}$ Rising anxiety about China is likely to result in a gradual but unmistakable shift of emphasis from the defence of the Japanese home islands to defence of Japan's maritime domain, and to greater cooperation with Australia and South Korea.

\section{Australia}

Unlike Japan, Australia has not had any direct military confrontations with the PLA that would justify immediate investments in military capabilities to counter the threat; however, like Japan, a growing number in Australia see China as the most likely direct threat in the coming decades. As a result of China's rise and the potential it has to destabilise the regional security status quo, Canberra has adopted a hedging strategy - increasing cooperation and defence links with Beijing while also strengthening its ties with the US and other nations and preparing to invest in the capabilities to confront a major power by sea and air. Public opinion would seem to back this strategy, as a growing number of Australians express concern over China's military modernisation. However, given Australia's distance from China, its close economic relationship, and budgetary issues, some Australian academics do not approve, believing that the "China threat" is an over-hyped excuse for military investment and that other types of military operations are more likely but ignored in the new policy.

\section{Official responses}

Over the past decade, Australia's defence policy has gradually adjusted to China's military modernisation. In the first half of the decade, Canberra's focus was largely on terrorism and small-scale operations, with an emphasis on the need to develop flexible and mobile capabilities to combat nontraditional threats or to perform peace-keeping, humanitarian assistance, or disaster relief missions. However, starting in 2005, though non-traditional missions remained the focal point, the Defence Department began to show more concern for the shifting strategic environment in the AsiaPacific caused by conventional military build-ups, saying that the Australian Defence Force (ADF) should be prepared for "a wide range of eventualities." The 2007 "Defence Update" showed an even greater awareness of the growth of the PLA and its effects on regional security, saying, "The ADF increasingly will be called on to fight irregular opponents... but we must also remain alert to more conventional military dangers." (55)

It was not until 2009, however, that Canberra realised that the shift in regional security dynamics required a fundamental re-evaluation of its defence policy. Australia's "Defence White Paper 2009" demonstrates that apprehension over traditional military threats has returned to the forefront. The paper highlights Canberra's dual concerns: the rise of China and the relative decline of the United States. It notes that China's military modernisation program will be characterised by the development of power projection capabilities and predicts China by 2030 will be "the strongest Asian military power, by a considerable margin." The paper also warns that while a major power of China's stature can be expected to develop a globally significant military capability befitting its size, a development that may ultimately lead to a stable multi-polar region, "The pace, scope and structure of China's military modernisation have the potential to give its neighbours cause for concern if not carefully explained, and if China does not reach out to others to build confidence regarding its military plans." At the same time, Australia's Defence Department predicts that by 2030, the US - the ally in whose hands Canberra has largely placed its security - may find itself "preoccupied and stretched in some parts of the world such that its ability to shift attention and project power into other regions, when it needs to, is constrained." Furthermore, the white paper concludes that due to uncertain economic futures, certain Asia-Pacific powers such as the US may face declining military budgets. China is expected to be able to maintain the ability to afford its military programs, however. ${ }^{(56)}$

Although the 2009 Defence White Paper makes developing a friendly defence relationship with China a priority, it also reflects a hedging strategy. On the one hand, Canberra hopes the US will still provide strategic reassurance two decades hence, and it does not rule out that Beijing will rise peacefully; at the same time, however, the paper says that Australia must

50. "China's Military Spending Still a Cause for Alarm," Asahi Shimbun, 6 March 2011.

51. "'Xi Jinping's China' - Concern Over Increase in Influence of Military," Sankei Shimbun, 20 October 2010.

52. "China's Military Buildup Worries International Community," Yomiuri Shimbun, 14 September 2010.

53. James J. Przystup, "Japan-China Relations: Looking for Traction," Comparative Connections, vol. 13, no. 1, May 2011.

54. Leithen Francis, "Three Fighters in the Running for Japanese FX Competition," Aerospace Daily \& Defense Report, 20 April 2011.

55. Department of Defence, "Australia's National Security: A Defence Update 2007," 2007, www.defence.gov.au/ans/2007/pdf/Defence_update.pdf (consulted on 30 November 2011).

56. Department of Defence, "Defending Australia in the Asia Pacific Century: Force 2030," 2009, www.defence.gov.au/whitepaper/docs/defence_white_paper_2009.pdf (consulted on 30 November 2011). 


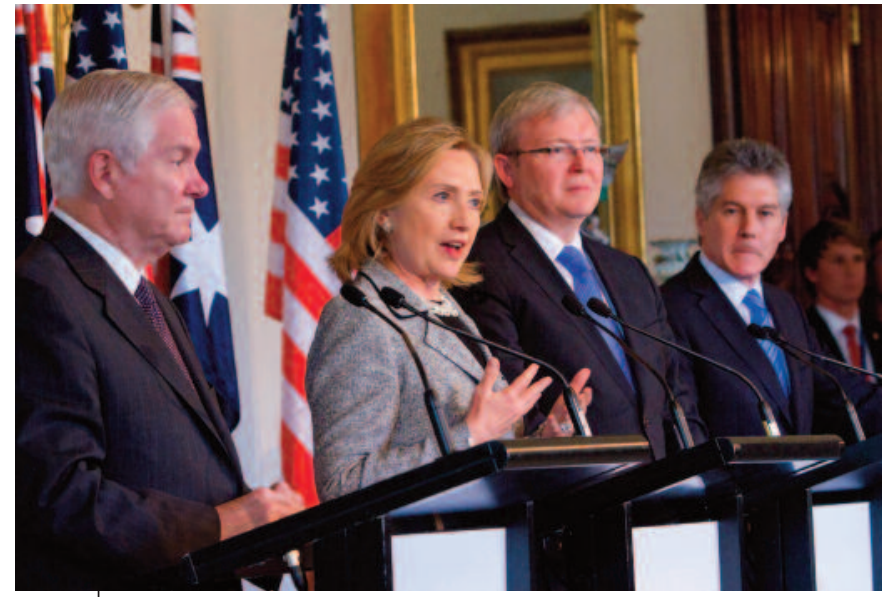

U.S. Secretary of State Hillary Rodham Clinton, second from left, speaks as U.S. Secretary of Defence Robert Gates, left, Australian Foreign Affairs Minister Kevin Rudd, second from right, and Australian Defence Minister Stephen Smith look on during a press conference after the annual Australia-United States Ministerial Consultations (AUSMIN) at Government House in Melbourne, Australia, on 8 November 2010. Source: State Department photo/Public Domain,

www.flickr.com/photos/statephotos/5162179102/in/photostream (consulted on 30 November 2011).

be prepared for the worst-case - and possibly more likely - scenario where China presents a threat and the US cannot effectively defend Australia. The hedging strategy calls for strengthening the alliance with the US and prioritising improved defence relations with China; at the same time, it calls for investing in the capabilities to enhance deterrence and defend Australia against the most likely aggressor (i.e., China), if necessary. ${ }^{(57)}$

Specifically, though it states that war between major powers is nearly unthinkable, the white paper concludes, "After careful examination, it is the Government's view that it would be premature to judge that war among states, including the major powers, has been eliminated as a feature of the international system." Significantly, despite the fact that this scenario is "nearly unthinkable," the Defence Department chose to prepare for it, calling for investments of AUS\$100 billion over the next two decades in maritime capabilities, special forces, aerial refuelling, airborne early warning and control, strategic strike, and force projection capabilities. ${ }^{(58)}$ As The Australian wrote at the time, "The rise of China will shape Australia's defence planning for a generation." (59)

The 2009 Defence White Paper was followed by a June 2011 announcement that the Defence Department would be conducting a major "force posture review" for the first time in two decades. Though the growth of the PLA was not specifically mentioned as an impetus, Defence Minister Stephen Smith did indicate that "the growth of military power projection capabilities of countries in the Asia Pacific" was a major concern. An expected result of the review is for a shift in focus for ADF forces to countries north and west to better protect Australia from Asian militaries, specifically China's. ${ }^{(60)}$

Additionally, Australia's leadership and defence apparatuses have hedged their bets on China's peaceful rise by boosting ties with allies and partners. Perhaps Canberra's most important move came in November 2010, when at the Australia-US defence and foreign ministers talks, the two sides announced an agreement that would allow for a "major escalation" in US military presence in the South Pacific, allowing for increased US access to Australian training exercise and test ranges, the prepositioning of US equipment in Australia, and greater use by the US military of Australian facilities and ports. ${ }^{(61)}$ In November 2011, President Obama and Prime Minister Gillard announced an agreement to deploy 2,500 US Marines to Australia permanently; Obama said that the US presence would not only increase military collaboration between the two countries but was also designed "to meet the demands of a lot of partners in the region that want to feel that....we have the presence that's necessary to maintain the security architecture in the region." (62) US access to Australia can be seen as a direct response to Australian concerns that PLA anti-access and area denial capabilities threaten the US ability to promptly respond to military crises in the region.

Aside from the US, Canberra has stepped up defence cooperation with India, Japan, South Korea, Indonesia, and Singapore. After joint military exercises and calls for greater military cooperation in late 2008, Australia and India entered into a "strategic partnership" and signed a "Joint Declaration on Security Cooperation" when Prime Minister Kevin Rudd travelled to New Delhi in November 2009. ${ }^{(63)}$ After reaffirming the Australia-Japan strategic partnership and boosting security cooperation in 2007, PM Gillard in April 2011 visited Tokyo, where she called for boosting defence cooperation between the two US allies even further; that meeting specifically involved consultations on the implications of China's rise. On the same trip, PM Gillard also looked to expand defence cooperation with South Korea. ${ }^{(64)}$ All of these actions can be seen as creating a concert of democracies in the Asia-Pacific, united not only by their common values but also by their concerns about China's military modernisation.

\section{Academic responses}

Within the Australian academic community, there exists a lively debate over how Australia should respond to China, and in particular whether Canberra should join the "arms race" in the Asia-Pacific. This back-and-forth was particularly loud after the release of the 2009 white paper. Many Aus-

57. Cameron Stewart and Patrick Walters, "Spy Chiefs Cross Swords over China as Kevin Rudd Backs Defence Hawks," The Australian, 11 April 2009.

58. Ibid.

59. Ibid.

60. Brendan Nicholson and Mark Dodd, "Defence Review to Boost US Role in Region," The Australian, 23 June 2011, www.theaustralian.com.au/national-affairs/defence-review-to-boost-us-role-inregion/story-fn59niix-1226080212802 (consulted on 30 November 2011).

61. See Rory Medcalf, "The Debate Down Under, in Context," CSIS Asia Policy Blog, 14 February 2011, http://cogitasia.com/babbage-report-kokoda-strategic-edge-in-2030-rory-medcalf-lowy (consulted on 30 November 2011); Brendan Nicholson. "US Forces Get Nod to Share Our Bases," The Australian, 6 November 2010; or Stephen Smith, Minister of Defence, Australia, "Asia's New Distribution of Power and its Implications," the 10th IISS Asia Security Summit (The Shangri-La Dialogue), 4 June 2011, www.iiss.org/conferences/the-shangri-la-dialogue/shangri-la-dialogue-2011/speeches/third-plenarysession/stephen-smith (consulted on 30 November 2011).

62. "Seeking to Contain China, US to Establish Permanent Military Presence Down Under," ABC News, 16 November 2011.

63. See Manmohan Singh and Kevin Rudd, "Joint Statement," 12 November 2009, www.hcindiaau.org/pdf/joint_statement.pdf (consulted on 30 November 2011); and also "Visit of Australian Foreign Minister Stephen Smith to New Delhi from 8-12 September 2008," Australian Department of Foreign Affairs and Trade, 8 September 2008, www.foreignminister.gov.au/releases/2008/fa-s142_08.html (consulted on 13 December 2011).

64. See Ministry of Foreign Affairs, "Japan-Australia Joint Declaration on Security Cooperation," 13 March 2007, www.mofa.go.jp/region/asia-paci/australia/joint0703.html (consulted on 30 November 2011); and also John Garnaut, "Cillard's defensive talk adds to China tensions," Sidney Morning Herald, 22 April 2011. 


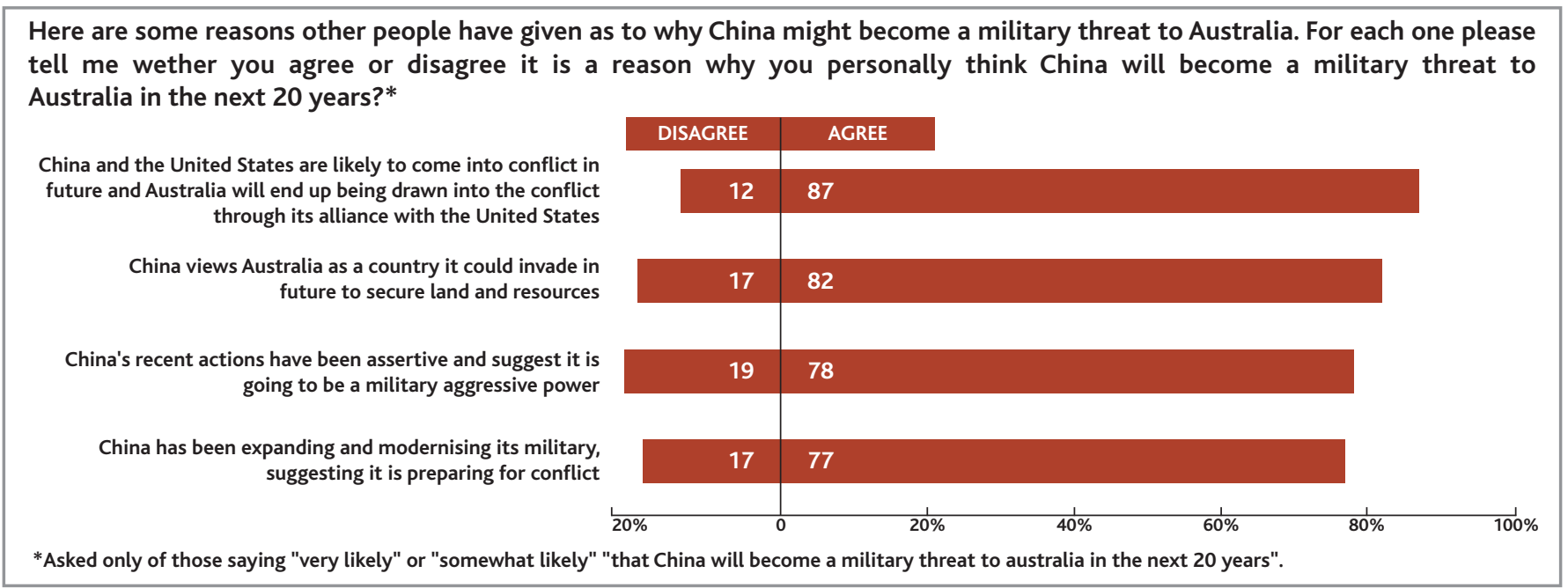

Source: Fergus Hanson, "Australia and the World: Public Opinion and Foreign Policy," Lowy Institute Poll 2010, 2010, http://www.lowyinstitute.org/Publication.asp?pid=1305 (consulted on 30 November 2011).

tralian academics supported the strategic shift, calling it "prudent" and "sound;" (65) however, two primary arguments arose against the white paper: the first challenged the premise that China was a threat that required a military response and the second argued against the force structure proposed in the paper.

In line with the first argument, Alan Dupont, director of the Centre for International Security Studies at the University of Sydney, maintained that it makes "no sense to allow worst-case assessments of China's intentions and capabilities to determine the next 20 years of Australian defence spending and strategy." Dupont contends that China shows no intent to dominate the region militarily, and even if it did, its capabilities do not match those of the US or even Japan. He concluded, "The notion that we should justify much of our future defence spending on the dubious assumption that the ADF needs to be able to deter or balance Chinese military power is neither a sensible basis for a defence strategy nor a reason for acquiring expensive capabilities that we do not need and cannot afford." (66) Rory Medcalf, director of the international security program at the Lowy Institute, argued that Australia should enhance cooperation with China, not compete militarily; further, he wrote, the white paper had the potential to spark an even greater arms race: "The problem is that many Asian countries may read our white paper as a sign they are not afraid enough: if the Australians, way down there, feel the need to revolutionise their firepower, they could think maybe we should redouble ours." (67) Rod Lyon of the Australian Strategic Policy Institute maintained that Australia cannot tell what China's intentions or capabilities will ultimately be in 2030 and therefore should not make the strategic decision to invest heavily to counter those capabilities in 2009. If China ultimately is belligerent, Lyon says, Canberra will have plenty of time to develop its capabilities before 2030; if China's military modernisation ultimately poses no threat, there is no need to waste the money. ${ }^{(68)}$

Among those who disagreed with the force structure changes proposed in the white paper, Hugh White of the Australian National University, writing in The Australian, asserted that the military build-up would be nearly impossible to fund, would likely be of little use even in a confrontation with China, and would leave Australia's ground force "too small to fill the tasks expected of it in places such as East Timor and Papua New Guinea." (69) Similarly, Alan Dupont told The Australian that the most likely future role for the ADF was on small-scale land operations, such as peacekeeping, not great power maritime and air operations. ${ }^{(70)}$ Writing from his perch as a US Army Federal Executive Fellow at the Brookings Institution, Colonel John Angevine maintained, "The plan...is focused on expensive maritime and air capabilities for conflicts the ADF couldn't fight alone. Consequently, the ADF is exposed with an atrophying ground force and expeditionary capability for the low-level regional operations in which it will be most likely to engage." (71)

While the vast majority of academics were divided between those who supported the White Paper's portrayal of China and those who judged that it went too far, one influential Australian military analyst did not think the document went far enough. Writing in February 2011, Ross Babbage of the Kokoda Foundation argued, "By 2030, the PLA's capabilities will probably pose an even more direct challenge to Australian sovereignty." To meet the challenge, he called on Canberra to completely revamp its defence organisation to create a force that could "deliver high asymmetric leverage against a coercive major power in close partnership with the United States." Proposed areas of investment include advanced space warfare capabilities designed "to interfere with Chinese space systems"; advanced underwater combat capabilities, such as nuclear-powered attack submarines; next-generation large strategic strike aircraft; prompt conven-

65. See, for example, "'Too Few Boots on the Ground'," The Australian, 4 May 2009; Gerard Henderson, "A Prudent Approach on China," Brisbane Times, 5 May 2009; or Kim Beazley, "In Defence of Sound Military Planning," Sydney Morning Herald, 4 May 2009.

66. Dupont, "Our forces must first be functional," The Australian, 14 April 2009

67. Rory Medcalf, "We Should Co-operate, Not Compete, with China's Rise," The Age, 29 April 2009.

68. Rod Lyon, "Changing Asia, Rising China, and Australia's Strategic Choices," Australian Strategic Policy Institute Policy Analysis, no. 40, April 2009

69. High White, "Muddled Report Leaves Gaps in Our Defence," The Australian, 4 May 2009.

70. "'Too Few Boots on the Ground'," The Australian, 4 May 2009.

71. John Angevine, "Dangerous Luxuries: How the Quest for High-End Capabilities Leaves the ADF Vulnerable to Mission Failure and More Dependent on the United States," Lowy Institute Analysis, June 2011, www.brookings.edu/ /media/Files/rc/papers/2011/0531_australian_defense_angevine/0531_australia_defense_angevine.pdf (consulted on 30 November 2011). 
tional strike capabilities to include long-range ballistic missiles; and "very advanced" cyber warfare capabilities. In addition, Babbage proposed allowing the US military greater access to Australian bases, and even basing American forces on Australian soil. (72)

\section{Public opinion}

Similar to both Japan and South Korea, Australia's public is increasingly concerned about China's military modernisation and its potential to destabilise regional security. A BBC World Service poll published in March 2011 showed that only 20 percent of Australians had a positive reaction to China becoming more powerful militarily, with 76 percent responding negatively (equal to the ROK but lower than the 88 percent who reported the same opinion in Japan). ${ }^{(73)}$ A 2010 Lowy Institute poll found that although 73 percent of Australians believed China's growth was good for their country, 69 percent nonetheless viewed China as trying to "dominate Asia" - a rise of nine points from the 2008 iteration of the same poll. Additionally, that survey found that 46 percent of Australians expect China will become a military threat in the next 20 years, an increase of six points from the previous year, even though a majority (52 percent) still anticipates China will not pose a military threat. ${ }^{(74)}$ As Andrew Shearer of the Lowy Institute argues, a shift in Australian thinking about China occurred in 2009, after China overtook Japan as Australia's largest trading partner. He writes, "For the first time, our major economic partner is a developing country with an authoritarian political system. It is pursuing increasingly assertive mercantilist policies, is rapidly modernising its military...and is emerging as a strategic competitor to the United States in Asia. As a result it is becoming increasingly difficult to align our strategic policies with our economic interests." (75) Overall, Australian public opinion largely tracks with the larger trend throughout the country; the nation is reacting to China's military rise and beginning to contemplate the level of threat posed and the response required by Canberra.

\section{South Korea}

The primary security concern in the Republic of Korea is, and will likely continue to be for many years to come, North Korea. Most of South Korea's military resources and planning are focused northward, and the changes in South Korean defence policy over the past decade have been driven primarily by the evolving security threat posed by Pyongyang. At the same time, China's military modernisation has frequently registered on Seoul's radar, though far less so than in Tokyo or Canberra. This is particularly true at times, such as 2010, when Beijing's support for its ally in the Democratic People's Republic of Korea (DPRK) is most obvious; at these moments, the growth of the PLA raises questions about China's intentions, particularly in a peninsular crisis, and increases concerns that China's military modernisation poses a threat to South Korean security.

In 2010, two major North Korean provocations had spill-over effects on South Korea's relationship with China, and the subsequent downturn in public opinion provoked calls for a greater ROK response to Beijing's military growth. In March 2010, the Cheon'an, a ROK naval vessel sailing near disputed waters, was struck by a torpedo, resulting in the deaths of 46 South Korean sailors. As most of the world condemned the DPRK, Beijing took weeks to convey its condolences to the ROK and promptly thereafter welcomed Kim Jong II to visit China; in the months that followed, China refused to assign blame, only calling the event "unfortunate" while insisting on the maintenance of peace and stability on the Korean Peninsula. (76)

Eight months after the sinking of the Cheon'an and only days after the DPRK revealed a previously unknown nuclear enrichment effort, North Korea fired more than 170 rounds of artillery on the ROK island of Yeonpyeong, killing two military personnel and two civilians and injuring 19. The ROK returned fire, causing damage to the North's deployments, and scrambled F-15 jets, though the aircraft did not engage. Pyongyang said the attack was in retaliation for South Korean artillery exercises that morning. In the aftermath of the bombardment, China's Foreign Ministry expressed "concern" but did not assign blame. ${ }^{(77)}$

\section{Official responses}

South Korea's defence policy has followed a curious trajectory over the last decade. In the early part of the decade, from a defence standpoint, North Korea remained the "main enemy," both literally in defence documents and in terms of defence planning. In 2004, after the improvement in North-South relations, Seoul looked beyond the DPRK, launching a major military modernisation effort in response to the growth of the militaries of China, Japan, Russia, and the US. In the 2006 Defence White Paper, the Defence Ministry wrote, "Most countries in the region are pursuing military transformation and technical innovation in order to modernise and enhance their military capabilities under the new security environment." (78) However, by the end of the decade and after countless provocative outbursts, North Korea had regained its status as the "main enemy," and military modernisation in countries such as China had largely lost the attention of Seoul. ${ }^{(79)}$

The ROK's most significant defence reform effort came in 2005 with the "Defence Reform 2020" plan. As originally proposed, the plan was not necessarily focused on North Korea but can instead be viewed as a response to regional military modernisation - in China but also in Japan and Russia - as well as an attempt to placate South Korea's security hawks during the years of the "Sunshine Policy." The 2020 plan had five goals: it called for quantitative reductions to forces coupled with qualitative improvements to weaponry; it increased civilian authority in the Defence Ministry; it augmented the role of the Joint Chiefs of Staff; it secured longterm military spending; and it sought to create a more equal alliance relationship with the US through an emphasis on greater capacity for autonomy and self-reliance. Importantly, the plan focused on personnel reductions while at the same time replacing outdated systems with advanced technologies, including advanced fighter jets, modern radar sys-

72. Ross Babbage, "Australia's Strategic Edge in 2030," Kokoda Papers, Number 15, February 2011.

73. "Rising Concern about China's Increasing Power: Global Poll," BBC World Service, 27 March 2011, www.globescan.com/news_archives/bbc2011_china/bbc_2011_China_global_rls.pdf (consulted on 13 December 2011).

74. Fergus Hanson, "Australia and the World: Public Opinion and Foreign Policy," Lowy Institute Poll 2010, 2010, www.lowyinstitute.org/Publication.asp?pid=1305 (consulted on 30 November 2011).

75. Andrew Shearer, "Sweet and Sour: Australian Public Attitudes towards China," Lowy Institute Analysis, August 2010, www.lowyinstitute.org/Publication.asp?pid=1360 (consulted on 30 November 2011).

76. "China Calls for Restraint Over Cheonan Sinking," Chosun Ilbo, 21 May 2010.

77. "China Expresses Concern over Alleged Exchange of Fire between DPRK, ROK," Xinhua, 23 November 2010.

78. Ministry of National Defence, Republic of Korea, "2006 Defence White Paper," 26 December 2006.

79. Ministry of National Defence, Republic of Korea, "2010 Defence White Paper," 13 December 2010. 


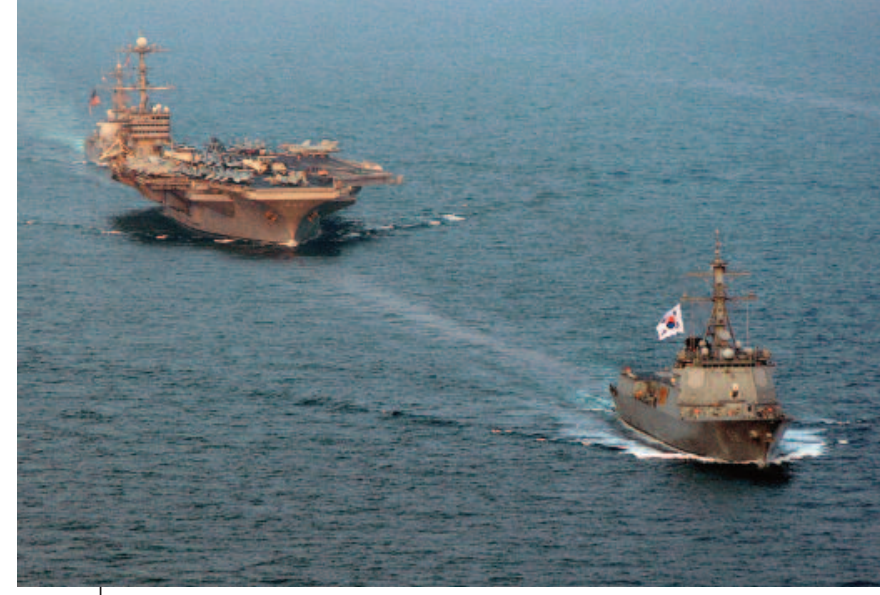

The aircraft carrier USS George Washington (CVN 73) and the Republic of Korea navy Aegis destroyer Sejong the Great (DDG KDX 991) transit in the Yellow Sea during a bilateral exercise on 13 October 2009. George Washington, the Navy's only permanently forward deployed aircraft carrier, is underway supporting security and stability in the region. (US Navy photo by Mass Communication Specialist 3rd Class Jeffrey Stewart).

Source: http://www.flickr.com/photos/us-pacific-command/4018136706 (consulted on 30 November 2011).

tems, Aegis-equipped naval forces, missile technologies, and submarines. ${ }^{(80)}$ As the ROK Minister of Defence explained, the plan would create a South Korean military that "sees farther, moves faster, and strikes more precisely" in an era of military modernisation. ${ }^{(81)}$ Possibly as a result of this effort, it was revealed in August 2011 that the ROK was developing a supersonic anti-ship cruise missile, with one military source explaining that the missile was intended "to cope with the threat from the navies of neighbouring big powers rather than the threat from North Korea." (82)

However, Pyongyang's provocations - including nuclear tests, missile firings, and the attacks of 2010 - along with the election of President Lee Myung Bak and the financial crisis of 2008-2009, altered South Korea's modernisation plan. In 2009, the original proposed spending for the Defence Reform 2020 plan was reduced by 30 percent as a result of evolving priorities and financial uncertainties. ${ }^{(83)}$ That same year, the Blue House proposed shifting the modernisation plan away from expensive naval and air forces and back toward ground forces and technologies designed to thwart a North Korean missile strike. ${ }^{(84)}$ And in 2011, after the Cheon'an and Yeonpyeong incidents, South Korea announced its "Defence Reform 307 " policy, intended to address some of the shortfalls within the South Korean military and command structure witnessed during the North Korean provocations of last year. Calling for a "paradigm shift" for the ROK military, Defence Minister Kim Kwan Jin said the 307 reform plan would shift the country from "passive defence to active deterrence" by investing in advanced technologies needed to combat North Korea, such as stealth fighters, missile defence, intelligence, surveillance, and reconnaissance technologies, and precision munitions. ${ }^{85)}$

South Korea's other method of preparing for the evolving regional security dynamics as a result of China's military modernisation has been to revitalise and rebalance its alliance relationship with the US. Though this is mostly geared toward North Korea, the improvement of the alliance has also helped to ensure a long-term US presence even beyond a divided peninsula. It is important to note that many of the major agreements between the allies occurred in the middle of the last decade, at the time when South Korea was focused beyond North Korea on creating a more self-reliant defence force to compete with other regional powers, including China. The two sides negotiated a reconfiguration in the US force posture in South Korea, reducing the number of troops, relocating and handing over bases, building more permanent facilities, and preparing for the transfer of wartime operational control from the US to South Korea (though this has since been delayed in the wake of North Korean provocations). (86)

One issue that has caused friction between the allies is the "strategic flexibility" of US forces stationed on the Korean Peninsula, with Seoul being concerned, in part, about China's negative reaction should the US use forces stationed in Korea for missions "off-peninsula." The crux of South Korea's hesitance is that Beijing would interpret strategic flexibility as targeting China - specifically that the ROK was granting US Forces in Korea the right to intervene in a Taiwan Strait crisis. Despite these concerns, in April 2011, US forces stationed in Korea deployed for the first time off the peninsula to partake in a training exercise in the Philippines, and it is likely that the movement toward strategic flexibility will proceed in the future. ${ }^{(87)}$

\section{Academic and editorial responses}

As with the government and Defence Ministry, South Korea's academic and editorial communities have expressed apprehension about China's military modernisation only episodically. Their concerns can be organised into three different categories. The first concern is over the strengthening of the PLA in the context of a larger regional arms race. A frequent worry has been that South Korea is being "sandwiched" between growing Chinese and Japanese militaries. ${ }^{(88)}$ Speaking in 2007, Jun Kyung Man, vice director of the state-run Korea Institute for Defence Analyses, expressed his concern that the regional arms race between Beijing and Tokyo threatened the denuclearisation of the Korean Peninsula because the two militaries were likely to stoke insecurity in Pyongyang. Jun called for the continuation of the modernisation proposed in the Defence Reform 2020, noting

80. See Han Yong-sup, "Analyzing South Korea's Defense Reform 2020," Korean Journal of Defense Analyses, vol. xVIII, no. 1, Spring 2006; Bruce W. Bennett, "A Brief Analysis of the Republic of Korea's Defense Reform Plan," Occasional Paper, RAND National Defense Research Institute, January 2006; and Choi Kang and Park Joon-sung, "An Assessment of the ROK's Defense and Security Requirements in Alternative Futures," NBR/KiFS US-ROK Alliance Conference Paper, September 2007, www.nbr.org/downloads/pdfs/PSA/USROK_Conf07_Choi.pdf (consulted on 30 November 2011).

81. Quoted in "Statement of General B. B. Bell, Commander, United Nations Command; Commander, Republic of Korea-United States Combined Forces Command; and Commander, United States Forces Korea, Before the Senate Armed Services Committee," 11 March 2008, www.dod.gov/dodgc/olc/docs/testBell080311.pdf (consulted on 30 November 2011).

82. "Supersonic Cruise Missile in Development," Chosun Ilbo, 17 August 2011.

83. Jung Sung-ki, "Less Spending for Military Modernization," Korea Times, 7 April 2009

84. Sam Kim, "S. Korea to Bolster Capabilities to Head Off N.K. Nuclear, Missile Attacks," Yonhap, 26 June 2009

85. See Lee Tae-hoon, "Seoul to Bolster Preemptive Strike Capability," Korea Times, 11 March 2011; Bruce Bennett, "The Korean Defense Reform 307 Plan," Issue Brief No. 8, Asian Institute for Policy Studies, April 2011; and Chang Gwang II, "ROK Military "Defense Reform 307 Plan," Korea Institute for Defense Analyses, ROK Angle: Korea's Defense Policy, Issue 47, March 2011.

86. Carin Zissis and Youkyung Lee, "The US-South Korea Alliance," Council on Foreign Relations Backgrounder, 28 August 2008, www.cfr.org/south-korea/us-south-korea-alliance/p11459 (consulted on 30 November 2011)

87. "The US 2nd Infantry's Participation in Philippines Training Exercises Is Cause For Concern," Kyunghyang Shinmun, 21 March 2011.

88. See "The US-South Korea Alliance," 28 August 2008 and "Arms Race in Northeast Asia," Korea Times, 27 April 2007. 
that even the significant military investment by the ROK was minor compared to that of China and Japan. ${ }^{(89)}$ Similarly, after the test flight of the PLA's stealth J-20 fighter in early 2011, Park Byung Kwang, a researcher at the Institute for National Security Strategy, wrote that Japan was already working to acquire a stealth jet and that the ROK "must also come up with a security strategy and an action plan against China's growing military aspirations." ${ }^{(90)}$ And after the release of the 307 reform, a Korea Times editorial criticised the plan for its single-minded focus on North Korea, asking "Should [not] the nation be also paying far greater attention to the two military giants in this part of the world - militarily resurgent Japan and China, who can already jump from regional to global military power?" (91)

The second concern in ROK commentary circles is the role of a confident and modernised PLA in a North Korean instability scenario. Writing in March 2010, Pak Ch'ang-hu'i of the Korea National Defence University argued that Chinese military intervention in a DPRK contingency scenario is "inevitable" due to Beijing's strong interest in influencing the outcome of the situation; the only question for Pak is, how will the PLA intervene: unilaterally against South Korea and the US, or multilaterally in cooperation with other regional powers? Either way, Pak concludes, Chinese intervention hurts the chances of the ROK-led unification effort and may even stand in the way of a unified peninsula altogether. To prevent this, he calls on Seoul to craft a "grand strategy for unification" that considers the pace and method by which Beijing's influence can be reduced. (92) Similarly, a Korea Herald editorial in response to rumoured ROK-US contingency planning discussions in November 2009 called on the allies to closely consider the role of the PLA in any situation: "No contingency plans... will have much significance without considering how China will respond when a chaotic situation prevails in North Korea." The editorial said the focus of any contingency plan should be on "how the allies can prevent China's military intervention in the event of a North Korean collapse." (93)

A final concern in ROK academic circles is that China's military might increasingly threaten the presence of the US in the region and this, in turn, raises questions as to whether South Korea should rely so heavily on its ally. Writing in February 2011, Chang Soo-man, commissioner of the ROK Defence Acquisition Program Administration, called on Seoul to increase investments in missile defence, saying that China's development of a "carrier killing" missile could limit US ability to intervene on behalf of the ROK. He writes, "China's development of the ASBM [anti-ship ballistic missile] could lead to significant changes in South Korea's military readiness, given that thus far the focus has been on preparations to counter North Korean ballistic missiles." (94) A Chosun Ilbo editorial from the same time warned, "If China boosts its defence investments in proportion to its 8-9 percent annual economic growth, the day is not far off when it approaches the US in military power as well." (95)

\section{Public opinion}

Since the normalisation of relations in 1992, public opinion toward China in the ROK has largely grown more positive. While other nations worried about PLA modernisation, the ROK embraced China's rise, emphasising the prospective economic benefits instead of the security threat. ${ }^{(96)}$ However, the effects of Beijing's support for North Korea in the face of its provocative actions, coupled with a number of nationalistic episodes between China and South Korea involving territorial and economic disputes, have reversed that trend. According to a $\mathrm{BBC}$ public opinion poll published in
March 2011, negative views regarding China's military modernisation in the ROK rose from 58 percent in 2005 to 76 percent in early 2011. ${ }^{(97)}$ In terms of opinions toward China writ large, a Hanguk Ilbo poll from late 2010 showed that 48.6 percent of South Koreans reported that the events of 2010 had negatively impacted their views of China. ${ }^{\left({ }^{88}\right)}$ And, a poll by the Asan Institute for Policy Studies showed an extraordinary 91 percent of South Koreans dissatisfied with China's response in the wake of the Yeonpyeong attack. ${ }^{(99)}$ Though this is more a commentary on Beijing's foreign policy than its military modernisation, it is possible that this decidedly negative shift in public opinion will spur louder calls for a firmer response in Seoul to the growth of the PLA. It remains to be seen how sustainable the ROK concern over the China threat will be, whether it is from the public, academics, or political leaders; recent history has shown that South Korea's current concern over China may only be temporary, and all eyes may soon return to the threat from the North.

\section{Conclusion}

Chinese military modernisation has raised varying degrees of concern in Japan, Australia, and South Korea. While there is a general hope that the region can accommodate China's rise peacefully, the PLA's evolving capability to project power beyond its shores, incidents in the bodies of water that connect these countries to China, and on-going friction and competition between the US and China have convinced Tokyo, Canberra, and Seoul that some measure of hedging is appropriate. Each is in different stages of this effort, and debate continues in all three capitals over how to craft an appropriate response to China's growing military power. Central to each country's strategy is the US, particularly in Japan and South Korea, where it is hoped the alliance can off-set limited domestic resources allocated for military expenditures. Yet questions about the long-term viability of the US regional presence continue to fester, and doubts persist about the ability of the US to deter Chinese coercive diplomacy and aggression given expanding Chinese area-denial capabilities and the likelihood of shrinking US defence spending.

Anxiety about China's military is greatest in Japan due to recent maritime encounters and lingering territorial disputes. Japan is shedding its traditional defensive strategy and taking a more active approach that utilises advanced technological platforms to detect and quickly respond to Chinese provocations across a vast maritime domain. Despite its qualitative

89. Jung Sung-ki, "S. Korea in Nutcracker of Regional Arms Race," Korea Times, 20 May 2007.

90. Park Byung-kwang, "China's Stealthy Wake-up Call," JoongAng Ilbo, 18 January 2011.

91. "Rebirth of Military," Korea Times, 9 March 2011.

92. Pak Ch'ang-hu'i, "A North Korea Contingency and China's Military Intervention Prospects," Kukka Cho'llyak (National Strategy), vol. 16, no. 1, 2010, (Open Source Center, no. KPP20100409024001).

93. "Contingency Plan," Korea Herald, 3 November 2009.

94. Chang Soo-man, "China's Development of an Anti-Ship Ballistic Missile and ROK-US Military Cooperation," Korea Institute for Defense Analyses, ROK Angle: Korea's Defense Policy, Issue 45, February 2011.

95. "Northeast Asia May Become 'Tinderbox' Amid PRC Military Build-up," Chosun Ilbo, 14 January 2011.

96. David Kang, "Between Balancing and Bandwagoning: South Korea's Response to China," Journal of East Asian Studies, vol. 9, no. 1, Jan-Apr 2009, and Jayshree Bajoria, "Countering China's Military Modernization," Council on Foreign Relations Backgrounder, February 2009, www.cfr.org/china/counteringchinas-military-modernization/p9052 (consulted on 30 November 2011).

97. BBC Global Poll, "Rising Concern about China's Increasing Power: Global Poll," 27 March 2011, www.worldpublicopinion.org/pipa/pdf/mar11/BBCChina_Mar11_rpt.pdf (consulted on 30 November 2011).

98. Kang Hyun-kyung, "Half of Koreans say China's Image Deteriorated," Korea Times, 31 December 2010.

99. Cited in Victor Cha and Ellen Kim, "US-Korea Relations: Under the Shadow of 2010," Comparative Connections, vol. 13, no. 1, April 2011. 
military advantage over China, however, the MSDF suffers from a quantitative disadvantage that will challenge it in its new, more active role. With a weak economy and the aftermath of the March 2011 earthquake to contend with, policymakers will have limited resources to devote to defence. Tokyo is hoping to overcome this by investing in partnerships, particularly with the US, and the alliance remains on solid footing. With concern about China among Japanese academics and the public on the rise, pressure will persist on Japanese politicians to continue Japan's security transformation. Still, lingering questions over the long-term viability of the US deterrent and continued turmoil in Japanese politics and its economy could frustrate Tokyo's long-term security ambitions.

Although physically far afield from China, Australian worries that China's military modernisation could upset the regional balance have increased, and policymakers do not want to be caught unprepared. Recent official defence reviews have noted the desirability of building friendly relations with China, while also hedging by boosting ties with the US and other regional partners. To enhance prospects for a continuing robust US regional presence over the long term, Canberra is planning to increase US access to Australian bases. Australian academics and the public are still unsure of what to make of China, however. While there is general receptivity to the idea of cooperation with regional partners, not all are convinced that Australia needs to commence expensive military investments. The pace and scale of Australia's reaction will depend heavily on events in the Asia-Pacific region in the coming decade, particularly the state of US-China relations.

South Korea's security strategy remains heavily geared towards a North Korean contingency. China's military modernisation has not escaped no- tice, however, with some worrying that Beijing could block a favourable outcome in the event of a Korean contingency. South Korea launched a major military modernisation program in the middle of last decade that was meant to equip the country to address other regional threats. This ambitious program has been scaled back, however, and the more advanced military capabilities that would be needed to confront China have given way to those that would assist US forces in a conflict with North Korea. South Korea has sought to revitalise its alliance with the US and is hoping that the US can continue to provide a credible deterring presence to potential aggressors. Yet South Koreans also seek to avoid exacerbating tensions with China and therefore do not favour forms of cooperation with the US that could be perceived by Beijing as threatening. South Korea's security strategy in the coming decades will likely be shaped primarily by inter-Korean affairs, although its focus could shift more towards China, particularly if Seoul sees China as negatively affecting inter-Korean relations. Various internal and external factors will affect the pace and scale of future Japanese, Australian, and Korean responses to the modernisation of China's military, including domestic politics in each country, economic sustainability, and unpredictable developments such as natural disasters. Yet even more important will be Chinese diplomatic and military behaviour and perceptions of American power. Benign Chinese policies will assuage concerns throughout the region about China's military, while repeats of incidents such as the September 2010 Senkaku row will fuel insecurity. Confidence in the US ability to maintain its security commitments in the region will encourage all three countries to forego independent responses or accommodations to Chinese military power that could be destabilising. 